\title{
Effect of Arbuscular Mycorrhizal Inoculum Rate on Tomato (Lycopersicum esculenta L.) Seedlings
}

\author{
MAH Bhuiyan ${ }^{*}, \mathrm{ME} \mathrm{Ali}^{2}, \mathrm{MR}_{\mathrm{Khatun}}^{3}$, F Alam ${ }^{4}$ and MB Banu ${ }^{5}$ \\ ${ }^{1}$ Principal Scientific Officer, Soil Microbiology Laboratory, Bangladesh Agricultural Research Institute, Gazipur-1701, Bangladesh; ${ }^{2}$ Senior Scientific Officer, \\ Soil Microbiology Laboratory, Bangladesh Agricultural Research Institute, Gazipur-1701, Bangladesh; ${ }^{3,4 \& 5}$ Scientific Officer, Soil Microbiology Laboratory, \\ Bangladesh Agricultural Research Institute, Gazipur-1701, Bangladesh
}

\begin{abstract}
An experiment on the effect of rate of arbuscular mycorrhiza inoculum in producing tomato seedlings (var. Ratan) were conducted in the seedbed of Soil Science Division, Bangladesh Agricultural Research Institute, Joydebpur, Gazipur, Bangladesh during rabi season of 2007-08 and 2008-09. Seven rates of AM inoculum viz. 0, 0.5, 1.0, 1.5, $2.0,2.5,3.0 \mathrm{~kg} \mathrm{~m}^{-2}$ were studied on tomato seedlings. Cowdung was used at the rate of $5 \mathrm{~kg} \mathrm{~m}^{-2}$ as basal. Seeds were sown in $10 \mathrm{~cm}$ apart solid lines on 13 November 2007 and 11 November 2008, and the seedlings were thinned down to about $3 \mathrm{~cm}$ from seedling to seedling within a week of germination. Ratan was used as the variety of tomato. Biomass yield, seedling height and nutrient uptake by tomato seedlings increased greatly with the use of AM inoculum. Biomass yield of tomato seedlings followed quadratic trend with the increase of AM inoculum rate from 0 to $1.0 \mathrm{~kg} \mathrm{~m}^{-2}$ in $2007-08$ and 0 to $2.0 \mathrm{~kg} \mathrm{~m}^{-2}$ in 2008-09.
\end{abstract}

Key words: Tomato, Arbuscular mycorrhiza, rate seedling

Arbuscular mycorrhiza is the most common type, occurring in about $80 \%$ of the plant species. They are the most suitable type for development programs based on low-input agriculture ${ }^{1}$. Arbuscular mycorrhiza form symbiotic association with most of the terrestrial plants species ${ }^{2-4}$. About $90 \%$ of all plant species including most agricultural, horticultural, and tree crops form mycorrhizae $^{5}$. More than 6,000 fungal species are capable of establishing mycorrhizas with about 240,000 plant species $^{6}$. Arbuscular mycorrhiza occurs in about $83 \%$ of dicotyledonous and $79 \%$ of monocotyledonous plants ${ }^{7}$. All gymnosperms are reported to be mycorrhizal ${ }^{8}$. Arbuscular mycorrhiza fungal associations have been observed in 1000 genera of plants representing 200 families. Arbuscular mycorrhizal fungi benefit plant in a number of ways to increase plant productivity and to conserve soil to sustain future production. The major benefits of AM association are: (i) an increase in uptake of immobile nutrients particularly phosphorus and micronutrients ${ }^{9-10}$; (ii) higher production of growth regulating substances ${ }^{11}$; (iii) increase in rate of photosynthesis ${ }^{12-13}$; (iv) increase in uptake of water and osmotic adjustment under drought stress ${ }^{12,14}$; (v) enhancement of symbiotic $\mathrm{N}_{2}$-fixation through increased $\mathrm{P}$ supply $^{15}$; (vi) resistance to pests and diseases ${ }^{1}{ }^{16}$; (vii) helps in the formation of soil aggregation and aggregate stability ${ }^{17}$; (viii) improves soil-plant-water relation ${ }^{12,18-19}$, and (ix) confers protection against toxic-metals ${ }^{20-21}$. Mycorrhizal association also helps in uptake of other macro-and micronutrients. A conservative estimate suggests that the external hyphae of AM can deliver up to $25 \%$ of N, $80 \%$ of P, $10 \%$ of K, $25 \% \mathrm{Zn}$ and
$60 \%$ of plant $\mathrm{Cu}^{22}$. The benefits from a mycorrhizal association depend largely on establishment of an effective association between the plant roots and AM fungus. Establishment of AM association depends on density and number of AM propagules (spore, mycelium, infected root pieces etc.) in the growing media. The present investigation was, therefore, undertaken to observe the effect of different rates of AM inoculum on the performance of tomato seedlings (var. Ratan).

An experiment on tomato seedlings was conducted in the seedbeds ( $3 \mathrm{~m} \times 1 \mathrm{~m}$ ) of Soil Science Division, Bangladesh Agricultural Research Institute, Joydebpur, Gazipur, Bangladesh during rabi season 2007-08 and 2008-09. Silted soil from the bank of Turag river at Kodda, Gazipur was used in the seedbed. The soil was slightly alkaline in reaction. Organic matter, major nutrients, and zinc and copper contents of the soil were low, while iron and manganese levels were quite high. The soil contained $10 \mathrm{AM}$ spores of indigenous mixed AM fungal species and the experiment was conducted under non-sterilized soil condition.

The experiment was laid out in randomized complete block (RCB) design with four replications. Seven rates of AM inoculum viz. $0,0.5,1.0,1.5,2.0,2.5,3.0 \mathrm{~kg} \mathrm{~m}^{-2}$ were studied on tomato seedlings. The seed bed was divided into 7 separate unit plot by inserting thick polyethylene sheet up to $25 \mathrm{~cm}$ depth of soil to check the contamination of AM among the plots. Cowdung was used at the rate of $5 \mathrm{~kg} \mathrm{~m}^{-2}$ as basal. No other

* Corresponding author:

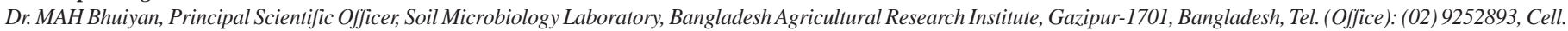
01720051657,E-mail:mahbhuiyan63@yahoo.com 
fertilizers were used. Seeds were sown in $10 \mathrm{~cm}$ apart solid lines on 13 November 2007 and 11 November 2008. Soil based AM inoculum was used in the seed furrows of about $3 \mathrm{~cm}$ depth. A soil layer of about $1 \mathrm{~cm}$ thickness was spread on the inoculum layer on which the seeds were sown. Ratan was used as the variety of tomato. The seedlings were thinned down to about $3 \mathrm{~cm}$ from seedling to seedling within a week of germination. Watering, weeding and other intercultural operation were done as and when necessary. The seedlings were harvested on 11 December 2007 and 17 December 2008. Data on biomass yield and yield components were recorded. The seedlings were harvested carefully by uprooting. Roots of the seedlings were washed to remove the adhered soils. Root samples were then excised for AM colonization studies. Plant samples were oven dried at $70^{\circ} \mathrm{C}$ until constant weight. Chemical analyses of the samples were done and nutrient uptake by the seedlings was calculated. Soil samples from the plot were collected during harvesting the seedlings for counting AM spore population. Hundred grams soil sample plot ${ }^{-1}$ was used to count the spore numbers. The spore numbers were determined by wet sieving and decanting method $^{23}$. To assess AM root colonization, the roots were processed after Koske and Gemma ${ }^{24}$ and observed under a compound microscope. Presence of fungal bodies (mycelium, spores, arbuscules and vesicles) in the root tissues were considered as positive for infection. Data were analyzed using the statistical package IRRISTAT and MSTAT-C.

Biomass yield of tomato seedlings (var. Ratan) has been presented in the Figs. 1 and 2. The biomass yield of the seedlings followed quadratic trend with the increase of AM inoculum rate. The response curve shows that the highest biomass (325 mg seedling $^{-1}$ in 2007-08 and 430 mg seedling $^{-1}$ in 2008-09) of tomato seedlings was produced with the AM inoculum rate of about $1.0 \mathrm{~kg} \mathrm{~m}^{-2}$ in 2007-08 and $2.0 \mathrm{~kg} \mathrm{~m}^{-2}$ in 2008-09. Similar

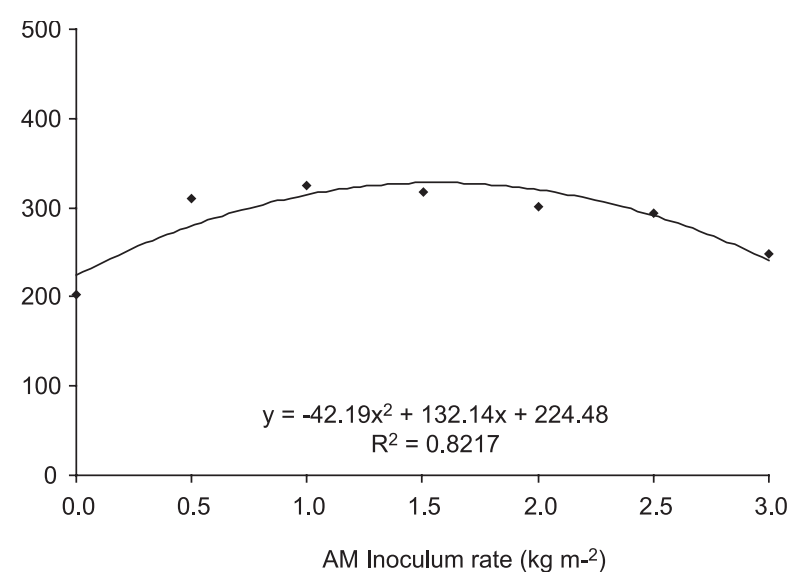

Figure 1. Effect of AM inoculum rate on dry weight of tomato seedlings (var. Ratan) during 2007-08. trend in the yield components like seedling height, root length, number of leaves seedling ${ }^{-1}$, collar diameter, shoot and root weight of the seedlings was also observed with the increase of AM inoculum rate (Table 1). Root colonization and spore population in tomato seedlings was found to increase with the increase of inoculum rate up to $2.0 \mathrm{~kg} \mathrm{~m}^{-2}$ and $2.5 \mathrm{~kg} \mathrm{~m}^{-2}$, respectively in 2007-08, and $2.0 \mathrm{~kg} \mathrm{~m}^{-2}$ and $2.0 \mathrm{~kg} \mathrm{~m}^{-2}$, respectively in 2008-09.

Uptake of all the major and minor nutrients increased greatly with AM inoculation, which might have enhanced the inoculated seedlings to produce more biomass and better growth compared to the non-inoculated seedlings (Tables 2 and 3.). Uptake of nutrients by non-inoculated seedlings was $6.36 \mathrm{mg} \mathrm{N}, 1.59 \mathrm{mg}$ P, $6.91 \mathrm{mg}$ K, $4.86 \mathrm{mg}$ Ca, $1.18 \mathrm{mg}$ Mg, $1.18 \mathrm{mg}$ S, $63 \mu \mathrm{g}$ B, $44.2 \mu \mathrm{g} \mathrm{Cu}, 789 \mu \mathrm{g}$ Fe, $166 \mu \mathrm{g}$ Mn and $77.0 \mu \mathrm{g} \mathrm{Zn}$ seedling ${ }^{-1}$ in 2007-08 and $7.87 \mathrm{mg} \mathrm{N}, 1.05 \mathrm{mg}$ P, $10.3 \mathrm{mg} \mathrm{K,} 3.58 \mathrm{mg} \mathrm{Ca}$, 1.92 mg Mg, 0.55 mg S, $122 \mu g$ B, $48.3 \mu g$ Cu, $1589 \mu g$ Fe, 216 $\mu \mathrm{g} \mathrm{Mn}$ and $172 \mu \mathrm{g} \mathrm{Zn}$ seedling ${ }^{-1}$ in 2008-09. While uptake of nutrients by inoculated seedlings ranged from 7.48 to 11.34 mg N, 2.08 to $2.64 \mathrm{mg}$ P, 9.15 to $12.00 \mathrm{mg} \mathrm{K}, 6.36$ to $8.81 \mathrm{mg}$ $\mathrm{Ca}, 1.56$ to $1.90 \mathrm{mg} \mathrm{Mg}$ and 1.68 to $2.76 \mathrm{mg} \mathrm{S}, 82$ to $165 \mu \mathrm{g} \mathrm{B}$, 49.7 to $77.0 \mu \mathrm{g} \mathrm{Cu}, 773$ to $1229 \mu \mathrm{g} \mathrm{Fe}, 189$ to $255 \mu \mathrm{g} \mathrm{Mn}$ and 74.9 to $132.6 \mu \mathrm{g} \mathrm{Zn}$ seedling ${ }^{-1}$ in $2007-08$ and 9.71 to 14.15 $\mathrm{mg} \mathrm{N}, 1.52$ to $2.19 \mathrm{mg}$ P, 13.9 to $19.1 \mathrm{mg} \mathrm{K}, 5.11$ to $7.08 \mathrm{mg}$ Ca, 2.75 to $3.52 \mathrm{mg} \mathrm{Mg,} 0.75$ to $1.19 \mathrm{mg} \mathrm{S}, 156$ to $247 \mu \mathrm{g}$ B, 61.3 to $89.9 \mu \mathrm{g} \mathrm{Cu}, 2073$ to $3192 \mu \mathrm{g}$ Fe, 305 to $404 \mu \mathrm{g} \mathrm{Mn}$ and 215 to $319 \mu \mathrm{g} \mathrm{Zn} \mathrm{seedling}{ }^{-1}$ in 2008-09. Trend in uptake of nutrients with increasing the rate was also observed.

From the results it is evident that the biomass yield, seedling height and nutrient uptake by tomato seedlings increased greatly with the use of AM inoculum. Biomass yield of tomato seedlings followed quadratic trend with the increase of AM inoculum rate.

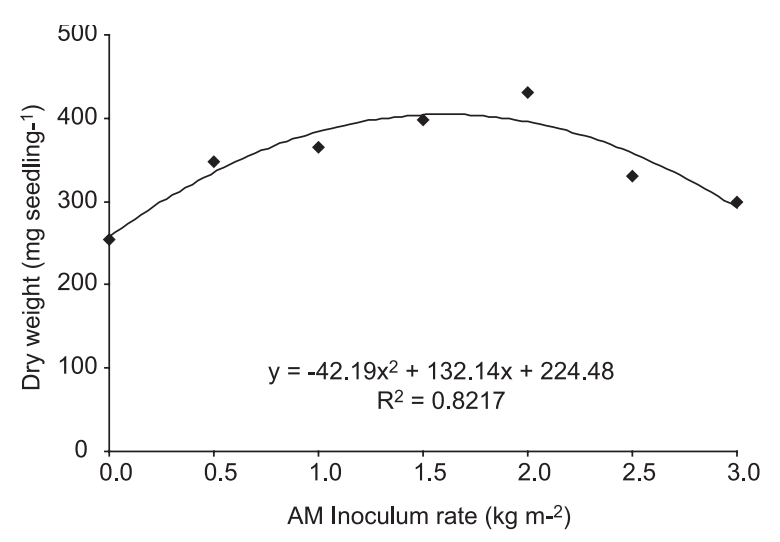

Figure 1. Effect of AM inoculum rate on dry weight of tomato seedlings (var. Ratan) during 2008-09. 
Table 1. Effect of rate of AM inoculum on the yield and yield components of tomato seedlings (var. Ratan) during rabi season of 2007-08 and 2008-09

\begin{tabular}{|c|c|c|c|c|c|c|c|c|}
\hline $\begin{array}{l}\mathrm{AM} \\
\text { Inoculum } \\
\text { rate } \\
\left(\mathrm{kg} \mathrm{m}^{-2}\right)\end{array}$ & $\begin{array}{l}\text { Seedling } \\
\text { height } \\
(\mathrm{cm})\end{array}$ & $\begin{array}{l}\text { Root } \\
\text { length } \\
(\mathrm{cm})\end{array}$ & $\begin{array}{c}\text { Collar } \\
\text { diameter } \\
(\mathrm{mm})\end{array}$ & $\begin{array}{c}\text { No. of } \\
\text { leaves } \\
\text { seedling-1 }\end{array}$ & $\begin{array}{c}\text { Shoot } \\
\text { weight } \\
\text { (mg } \\
\text { seedling-1) }\end{array}$ & $\begin{array}{c}\text { Root } \\
\text { weight } \\
\text { (mg } \\
\text { seedling-1) }\end{array}$ & $\begin{array}{c}\text { Root } \\
\text { coloni- } \\
\text { zation } \\
(\%)\end{array}$ & $\begin{array}{c}\text { Spore no. } \\
\left(100^{-1} \mathrm{~g}\right. \\
\text { soil) }\end{array}$ \\
\hline \multicolumn{9}{|l|}{$2007-08$} \\
\hline 0 & 14.7 & 5.1 & 2.15 & 4.30 & 181 & $22 c$ & $10.0 \mathrm{~d}$ & $10.0 \mathrm{~d}$ \\
\hline 0.5 & 17.7 & 7.4 & 3.11 & 5.40 & 266 & $45 \mathrm{ab}$ & $30.0 c$ & $15.0 \mathrm{~cd}$ \\
\hline 1.0 & 18.9 & 7.4 & 3.10 & 5.40 & 277 & $48 a b$ & $40.0 \mathrm{bc}$ & 20.0cd \\
\hline 1.5 & 22.9 & 5.9 & 3.31 & 5.50 & 265 & $52 a$ & $60.0 \mathrm{a}$ & $25.0 \mathrm{bc}$ \\
\hline 2.0 & 20.0 & 5.9 & 2.72 & 5.20 & 247 & $54 a$ & $45.0 \mathrm{~b}$ & $35.0 \mathrm{~b}$ \\
\hline 2.5 & 17.4 & 5.7 & 2.72 & 5.10 & 260 & 33bc & $40.0 \mathrm{bc}$ & $55.0 \mathrm{a}$ \\
\hline 3.0 & 17.4 & 5.7 & 2.65 & 5.30 & 223 & $26 c$ & $40.0 \mathrm{bc}$ & $50.0 \mathrm{a}$ \\
\hline F Test & NS & NS & NS & NS & NS & $* *$ & $* *$ & $* *$ \\
\hline CV (\%) & 12.2 & 10.3 & 12.7 & 8.6 & 12.8 & 15.4 & 14.7 & 16.3 \\
\hline \multicolumn{9}{|l|}{ 2008-09 } \\
\hline 0 & $20.6 c$ & 5.7 & 2.56 & 5.20 & 223d & 32 & $25.0 d$ & $20.0 \mathrm{~d}$ \\
\hline 0.5 & 27.4ab & 6.4 & 2.70 & 5.40 & $307 a b c$ & 41 & $30.0 \mathrm{~d}$ & $25.0 \mathrm{~d}$ \\
\hline 1.0 & 28.6ab & 7.1 & 2.78 & 5.85 & 323abc & 42 & $40.0 \mathrm{c}$ & $40.0 \mathrm{c}$ \\
\hline 1.5 & 28.8ab & 7.4 & 2.99 & 6.05 & $355 a b$ & 43 & 50.0b & $50.0 \mathrm{~b}$ \\
\hline 2.0 & $30.7 \mathrm{a}$ & 7.3 & 3.15 & 5.90 & $380 \mathrm{a}$ & 50 & $60.0 \mathrm{a}$ & $60.0 \mathrm{a}$ \\
\hline 2.5 & 24.3bc & 7.3 & 2.97 & 5.15 & 283bcd & 48 & $60.0 \mathrm{a}$ & $50.0 \mathrm{~b}$ \\
\hline 3.0 & 24.1bc & 7.1 & 2.86 & 5.35 & 259cd & 40 & $55.0 \mathrm{ab}$ & 50.0b \\
\hline F Test & $* *$ & NS & NS & NS & $* *$ & NS & $* *$ & $* *$ \\
\hline CV (\%) & 12.3 & 15.3 & 14.8 & 10.0 & 15.8 & 19.4 & 12.9 & 15.4 \\
\hline
\end{tabular}

Means followed by common letter are not significantly different at $5 \%$ level by DMRT

Table 2. Effects of rate of AM inoculum on uptake of major nutrients by tomato (var. Ratan) seedlings during rabi seasons of 2007-08 and 2008-09

\begin{tabular}{|c|c|c|c|c|c|c|}
\hline \multirow{2}{*}{$\begin{array}{l}\text { AM } \\
\text { Inoculum rate } \\
\left(\mathrm{kg} \mathrm{m}^{-2}\right) \\
\end{array}$} & \multicolumn{6}{|c|}{ Uptake of major nutrients (mg seedling ${ }^{-1}$ ) } \\
\hline & $\mathrm{N}$ & $\mathrm{P}$ & $\mathrm{K}$ & $\mathrm{Ca}$ & Mg & $\mathrm{S}$ \\
\hline 0 & $6.36 \mathrm{~d}$ & $1.59 c$ & 6.91c & $4.86 c$ & 1.18 & $1.18 \mathrm{~d}$ \\
\hline 0.5 & 9.60abc & $2.67 a$ & 10.66ab & 7.43ab & 1.73 & 2.76a \\
\hline 1.0 & $11.34 a$ & $2.64 \mathrm{ab}$ & $12.00 \mathrm{a}$ & $8.81 \mathrm{a}$ & 1.90 & $2.54 \mathrm{ab}$ \\
\hline 2.5 & 8.51cd & $2.08 \mathrm{bc}$ & $9.25 b c$ & $6.48 b c$ & 1.56 & $2.03 \mathrm{bc}$ \\
\hline 3.0 & 7.48cd & 2.38ab & 9.15bc & 6.36bc & 1.63 & $1.68 \mathrm{c}$ \\
\hline F test & $*$ & $*$ & $*$ & $*$ & NS & $* *$ \\
\hline CV(\%) & 10.0 & 9.4 & 9.9 & 10.0 & 9.7 & 10.1 \\
\hline \multicolumn{7}{|l|}{ 2008-09 } \\
\hline 0 & 7.87c & $1.05 \mathrm{c}$ & $10.3 d$ & $3.58 c$ & $1.92 \mathrm{c}$ & $0.55 d$ \\
\hline 2.5 & $11.15 b$ & $1.67 b$ & $15.3 b c$ & $5.26 \mathrm{~b}$ & 2.96ab & $0.91 \mathrm{bc}$ \\
\hline 3.0 & $9.71 b c$ & $1.52 \mathrm{~b}$ & $14.3 \mathrm{c}$ & $5.11 b$ & $2.75 b$ & $0.87 b c$ \\
\hline F test & $* *$ & $* *$ & $* *$ & $* *$ & $* *$ & $* *$ \\
\hline CV(\%) & 14.6 & 15.2 & 14.1 & 15.5 & 13.6 & 14.8 \\
\hline
\end{tabular}

Means followed by common letter are not significantly different at $5 \%$ level by DMRT 
Bhuiyan et al.

Table 3: Effects of rate of AM inoculum on uptake of minor nutrients by tomato (var. Ratan) seedlings during rabi seasons of 2007-08 and 2008-09

\begin{tabular}{|c|c|c|c|c|c|}
\hline \multirow{2}{*}{$\begin{array}{l}\text { AM Inoculum } \\
\text { rate }\left(\mathrm{kg} \mathrm{m}^{-2}\right)\end{array}$} & \multicolumn{5}{|c|}{ Uptake of minor nutrients ( $\mu$ g seedling ${ }^{-1}$ ) } \\
\hline & $\mathrm{B}$ & $\mathrm{Cu}$ & $\mathrm{Fe}$ & $\mathrm{Mn}$ & $\mathrm{Zn}$ \\
\hline \multicolumn{6}{|l|}{ 2007-08 } \\
\hline 0 & $63 c$ & $44.2 \mathrm{c}$ & 789c & $166 c$ & $77.0 \mathrm{~d}$ \\
\hline 0.5 & $158 \mathrm{a}$ & $77.0 \mathrm{a}$ & $1229 a$ & $255 a$ & 114.3ab \\
\hline 1.0 & $165 a$ & $74.1 \mathrm{a}$ & $1141 \mathrm{ab}$ & 224ab & 132.6a \\
\hline 1.5 & $110 \mathrm{~b}$ & $71.1 \mathrm{a}$ & $1115 a b$ & $244 a b$ & $97.8 \mathrm{bcd}$ \\
\hline 2.0 & $96 b$ & 63.6ab & $1151 \mathrm{ab}$ & $238 a b$ & $110.8 \mathrm{abc}$ \\
\hline 2.5 & $82 \mathrm{bc}$ & 49.7bc & 963bc & 189bc & 89.2cd \\
\hline 3.0 & $104 \mathrm{~b}$ & $50.4 \mathrm{bc}$ & $773 \mathrm{c}$ & 207abc & $74.9 \mathrm{~d}$ \\
\hline F test & $* *$ & $* *$ & * & $*$ & $* *$ \\
\hline CV(\%) & 10.8 & 9.8 & 9.5 & 10.0 & 9.7 \\
\hline
\end{tabular}

2008-09

0

$122 \mathrm{~d}$

48.3d $\quad 1589$ c

216c

$172 d$

0.5

$215 \mathrm{ab}$

$71.1 \mathrm{bc}$

2202b

333ab

252bc

1.0

233a

74.7bc

2742a

$370 \mathrm{ab}$

250bc

1.5

262a

83.4ab

2748a

$370 \mathrm{ab}$

299ab

2.0

247a

89.9a

3192a

404a

319a

2.5

$181 \mathrm{bc}$

$64.3 \mathrm{c}$

2073bc

310b

224cd

3.0

156cd

61.3cd

2086bc

305b

215cd

F test

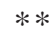

13.8

14.6

14.8

14.2

Means followed by common letter are not significantly different at $5 \%$ level by DMRT

\section{References}

1. Bethelenfalvay GJ and Linderman RG. 1992. Mycorrhizae in Sustainable Agriculture. American Soc. Agron. Special Publication No. 54. Medison. USA.

2. Azizah H. 1999. The endomycorrhiza: a futile investment? Syarahan Inaugural. Oct. 23, 1999. Dewan Fakulti Pertanian. Universiti Putra Malaysia, Serdang, Malaysia.

3. Richardson DM, Allsopp N, Antonio, CMD, Milton SJ and Rejmanek M. 2000. Plant invesions - the role of mutualisms. Biol. Rev. Cambridge Phyl. Soc. 75: 65-93.

4. Sramek F, Dubsky M and Vosatka M. 2000. Effect of arbuscular mycorrhizal fungi and Trichoderma harzianum on three species of balcony plants. Rostlinna Vyroba. 146: 127-131.

5. Read DJ, Lewis DH, Fitter AH and Alexander IJ. 1992. Mycorrhizas in Ecosystems. CAB International. Oxford.

6. Bonfante P and Perotto S. 1995. Strategy of arbuscular mycorrhizal fungi when infecting host plants. New Phytol. 130: 3-21.

7. Trappe JM. 1987. Phylogenetic and ecological aspects of mycotrophy in the angiosperms from an evolutionary standpoint. In: Safir GR. (eds.) Ecophysiology of VA Mycorrhizal Plants. CRC Press. Boca Raton. pp. 5-25.
8. Newman EL and Reddell P. 1987. The distribution of mycorrhizas among families of vascular plants. New Phytol. 106: 745-751.

9. Azizah H and Martin K. 1992. The vesicular-arbuscular mycorrhiza and its effects on growth of vegetatively propagated Theobroma cacao L. Plant Soil. 144: 227-233.

10. Douds DD and Millner P. 1999. Biodiversity of arbuscular mycorrhizal fungi in agroecosystems. Agric. Ecosyst. Environ. 74: 77-93.

11. Danneberg G, Latus C, Zimmer W, Hundes Hagen B, Schneider-Poetsch H and Bothe H. 1992. Influence of vesicular-arbuscular mycorrhiza on phytohormone balances in maize (Zea mays L.). J. Plant Physiol. 141: 33-39.

12. Masri BM. 1997. Mycorrhizal inoculation for growth enhancement and improvement of the water relations in mangosteen (Garcinia mangostana L.) seedlings. Ph.D. Thesis. Universiti Putra Malaysia. Serdang, Malaysia.

13. Syvertsen JP and Graham JH. 1999. Phosphorus supply and arbuscular mycorrhizas increase growth and net gas exchange response in two Citrus spp. grown at elevated $\mathrm{CO}_{2}$. Plant Soil. 208: 209-219.

14. Auge RM, Schekel KA and Wample RL. 1986. Osmotic adjustment in leaves of VA mycorrhizal and nonmycorrhizal rose plants in response to drought stress. Plant Physiol. 82: 765-770. 
15. Kucey RMN and Paul EA. 1982. Carbon flow, photosynthesis and $\mathrm{N}_{2}$ fixation in mycorrhizal and nodulated fababeans (Vicia faba L.). Soil Biol. Biochem. 14: 407-412.

16. Ho CT. 1998. Safe and efficient management systems for plantation pests and diseases. The Planter. 74: 369-385.

17. Azizah H and Idris ZA. 1996. Microbes: how they can do wonders to soil fertility. Malaysian Technology Bulletin. 4: 92-94.

18. Kothari SK, Marschner H and George E. 1990. Effect of VA mycorrhizal fungi and rhizosphere microorganisms on root and shoot morphology, growth and water relations of maize. New Phytol. 116: 303-311.

19. Jastrow JD, Miller RM and Lussenhop J. 1998. Contributions of interacting biological mechanisms to soil aggregate stabilization in restored prairie. Soil Biol. Biochem. 30: 905-916.
20. Azizah H, Puziah S and Chan YK. 1989. Growth response of selected fruit seedlings to VA inoculation in acid-sulphate soils. In: Proc. National Seminar on Soil Management for Food and Fruit Crop Production. Mar. 28-29, 1989. Kuala Lumpur, Malaysia. pp. 111-118.

21. Bonifacio E, Nicolotti G, Zanini E and Cellerino G.P. 1999. Heavy metal uptake by mycorrhizae of beech in contaminated and uncontaminated soils. Fresenius Environ. Bull. 7: 408-413.

22. Marschner H and Dell B. 1994. Nutrient uptake in mycorrhizal symbiosis. Plant Soil. 159: 89-102.

23. Gerdemann JW and Nicolson TH. 1963. Spores of mycorrhizal endogone extracted from soil by wet sieving and decanting. Trans. Brit. Mycol. Soc. 46: 235-244.

24. Koske RE and Gemma JN. 1989. A modified procedure for staining roots and detects VA mycorrhizas. Mycol. Res. 92: 486-505. 